\title{
KAJIAN TEORITIS METODOLOGI PEMBELAJARAN BAHASA ARAB
}

\author{
Rubini, Hani Zahrani \\ STAI Masjid Syuhada Yogyakarta \\ RubiniHr80@gmail.com, hany08578@gmail.com
}

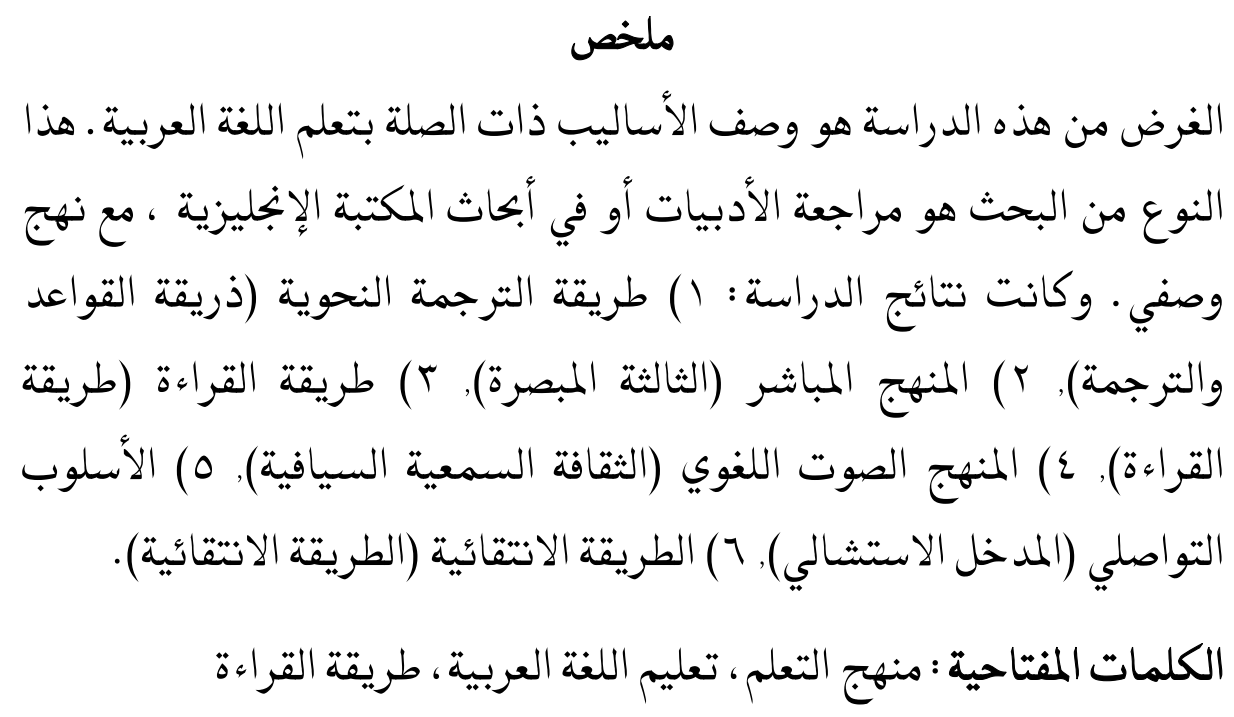

\section{Abstract}

The purpose of this study is to describe the methods that are relevant to learning Arabic. This type of research is literature review or in English library research, with a descriptive approach. The results of the research are (1) Grammatical-Translation Method (Thoriqah al Qawa'id wa al Tarjamah) (2) Direct Method (alThariqah al-Mubasyarah) (3) Reading Method (Thariqah al-Qirâ'ah) (4) Method Audio Lingual (al-Thariqah al Sam'iyah al-Syafahiyah) (5) Communicative Method (Al-Madkhal al-Ittashâliy) (6) Eclectic Method (Ath-Thariqah al-Intiqâ'iyyah).

Keywords: Learning Methodology, Arabic Language Education, Thariqah al-Qirâ'ah 


\section{Pendahuluan}

Pemilihan metode pembelajaran sangatlah penting. Karena pendidik dapat memilih kegiatan pembelajaran yang paling efektif dan efisien untuk menciptakan pengalaman belajar yang baik, yaitu yang dapat memberikan fasilitas kepada peserta didik mencapai tujuan pembelajaran. namun, harus diingat bahwa tidak ada satupun strategi pembelajaran yang paling sesuai untuk semua kondisi dan situasi yang berbeda,Walaupun tujuan pembelajaran yang ingin dicapai sama. Oleh karena itu, dibutuhkan kreativitas dan ketrampilan pendidik dalam memilih dan menggunakan strategi pembelajaran, yaitu yang disusun berdasarkan karakteristik peserta didik dan situasi kondisi yang dihadapinya.

Proses belajar yang tidak menarik ketika dilaksanakan dikelas, akan memicu kebosanan di dalam diri peserta didik, sehingga disetiap mata pelajaran yang diajarkan oleh pendidik tersebut, maka peserta didik mempunyai penilaian tersendiri terhadap pendidik tersebut. Penilaian peserta didik sudah tentu menyangkut kebosanan mereka terhadap proses belajar, penilaian ini bukan berangkat pada pikiran yang abstrak, tetapi dari pengalaman para peserta didik itu sendiri. Maka dari itu pendidik perlu meningkatkan kualitas mereka di dalam hal menyampaikan mata pelajaran itu dengan menarik.

Mewujudkan tujuan pendidikan perlu adanya upaya-upaya dalam menyelenggarakan pendidikan, seperti peningkatan interaksi timbal balik antara peserta didik dan pendidik, ataupun 
interaksi antara satu peserta didik dengan peserta didik yang lainnya. Interaksi timbak balik tersebut dapat berupa perlakuan khusus pada saat proses belajar mengajar berlangsung.

Peserta didik hendaknya menggunakan berbagai variasi atau metode dalam proses belajar mengajar, satu proses yang monoton saja akan tidak efektif, tidak jalan, peserta didik menjadi pasif, sehingga keberanian tidak berkembang. Penggunaan strategi pembelajaran yang sebagian besar dilakukan pendidik dengan mengedepankan peran pendidik. Hal ini menyebabkan peserta didik kurang berperan sehingga akhirnya nilai yang diraihnya kurang dari yang diharapkan. Dengan metode pembelajaran yang tepat diharapkan peserta didik dapat menggali dan menemukan pokok materi secara bersama-sama dalam kelompok atau secara individu. Sehingga materi yang dipelajari melekat dalam benak peserta didik karena didapatkan dari pengalaman sendiri.

Bahasa Arab merupakan bahasa Al Qur'an. Ini menunjukkan bahwa bahasa Arab sangat terkait dengan agama Islam, karena kitab suci agama Islam adalah Al Qur'an yang berbahasa Arab begitu pula dengan Hadits yamg merupakan penjelas dan penafsiran Al Qur'an yang dihimpun dan disusun dalam bahasa Arab. Bahasa Arab juga merupakan salah satu mata pelajaran yang diajarkan pada sekolah atau lembaga pendidikan Islam.

Permasalahan yang masih muncul sampai saat ini adalah proses pelaksanaan kegiatan pembelajaran khususnya 
pembelajaran bahasa Arab yang berlangsung di kelas masih berfokus pada pendidik sebagai sumber perangkat fakta-fakta yang harus dihafal, kemudian ceramah menjadi pilihan utama sebagai strategi pembelajaran.

\section{Pengertian Pembelajaran Bahasa Arab}

Pembelajaran menurut Depdiknas adalah proses interaksi antara peserta didik dan pendidik dan sumber belajar pada suatu lingkungan belajar baik lingkungan pendidikan formal maupun non-formal.25 Sedangkan menurut Dengeng, pembelajaran mengacu pada upaya membelajarkan peserta didik. ${ }^{26}$ Sehingga dapat dipahami bahwa pembelajaran merupakan upaya pendidik terhadap peserta didik dalam interaksi belajar supaya siswa dapat mempelajari sesuatu dengan efektif dan efisien.

Pengajaran bahasa ibu atau bahasa pertama lebih mudah karena terjadi secara alamiah melalui kegiatan dengan orang tuanya dan lingkungannya. Berbeda dengan bahasa asing, pengajarannya cenderung lebih sulit karena bahasa tersebut jarang digunakan atau bahkan tidak pernah sebelumnya sehingga penguasaan kosa kata dan struktur kalimatnya tidak dikenal oleh masyarakat itu. Oleh karena itu pengajaran bahasa asing 2008), hlm 31.

${ }^{25}$ Depdiknas, Kamus Besar Bahasa Indonesia, (Jakarta. Balai Pustaka,

${ }^{26}$ Dengeng, I. N. S, Kerangka Perkuliahan dan Bahan Pengajaran, (Jakarta. Proyek Pengembangan Lembaga Pendidikan Tenaga Kependidikan, 1989), hlm 50.

\section{IHTIMAM}


membutuhkan banyak waktu dan latihan yang teratur dan terus menerus sampai bahasa asing tersebut bisa terkondisikan dan terbiasa bagi masyarakat yang mempelajarinya, demikian juga dengan bahasa arab. Dari berbagai devinisi diatas dapat diambil kesimpulan bahwa pembelajaran bahasa Arab adalah suatu upaya pendidik terhadap peserta didik dalam interaksi belajar bahasa Arab supaya siswa dapat mempelajari sesuatu dengan efektif dan efisien.

Ada tiga hal penting yang saling terkait dan tidak dapat dipisahkan agar siswa dapat menguasai bahasa Arab sebagai bahasa asing, yaitu: interest (ketertarikan), practice ( berlatih menggunakan) dan long time (waktu yang lama). ${ }^{27}$

\section{Prinsip- Prinsip Pembelajaran Bahasa Arab}

Berkaitan dengan pembelajaran bahasa Arab sebagai bahasa asing, ada beberapa prinsip yang harus diperhatikan dalam pengajarannya, antara lain:

1. Prinsip ujaran sebelum tulisan.

Pengajaran bahasa hendaknya dimulai dengan melatih pendengaran, percakapan kemudian dilanjutkan dengan bacaan dan tulisan.

2. Prinsip kalimat-kalimat dasar.

Pengajaran dengan memberikan latihan kepada peserta

27 Ulin Nuha, Metodologi Super Efektif Pembelajaran Bahasa Arab, (Diva Press : Jogjayakarta, 2000), hlm. 20-24 
didik untuk menghafalkan kalimat-kalimat dialog dasar secermat mungkin. Penggunaan percakapan yang berupa dialog ini sangat penting karena percakapan menghidangkan kata-kata dalam struktur kalimat dan dalam konteks sehingga akan dapat menjadi model dan untuk belajar lebih lanjut.

3. Prinsip Pola Sebagai Kebiasaan.

Pembelajaran bahasa Arab diberikan dengan menanamkan kepada peserta didik pola- pola sebagai kebiasaan melalui praktek pola. Mengetahui katakata, kalimat- kalimat terpisah, atau aturan- aturan tata bahasa bukanlah mengetahui bahasa. Berbincang mengenai bahasa bukanlah berarti mengetahuinya. Mengetahui bahasa adalah memakai pola- pola dengan vokabulari yang sesuai dengan kecakapan yang sedang untuk komunikasi.

4. Prinsip Sistem Bunyi untuk digunakan.

Pembelajaran bahasa Arab diberikan dengan mengajarkan struktur sistem bunyi untuk digunakan dengan cara demonstrasi, tiruan, bantuan, kontras dan drill. Percobaan sebagian dan bantuan dalam bentuk ide yang jelas ucapannya dan kontras minimal ( melatih peserta didik mengucapkan fonem- fonem dengan memberikan dua contoh dua form yang hampir berdekatan bunyinya) untuk memutuskan perbedaan fonem dengan teliti yang akhirnya akan menghasilkan jawabanjawaban yang memuaskan. 
5. Prinsip-Prinsip Kontrol Vocabulari.

Pembelajaran bahasa Arab yang mengajarkan vokabulari, perlu dikontrol pemberiannya kepada siswa. Tahanlah pada permulaan beban vokabulari kepada kata-kata yang dibutuhkan untuk memberi pengertian pola-pola atau untuk mengilustrasikan bunyi-bunyi serta kontras-kontrasnya. Kembangkanlah vokabulari sesuai dengan tingkat kemampuan pelajar dan ajarkanlah vokabulari yang dikhususkan apabila struktur dasar telah dikuasai.

6. Prinsip Pengajaran Problema- Problema.

Pembelajaran bahasa arab adalah dengan mengajarkan unit-unit dan pola pola yang menunjukkan perbedaan struktur antara satu bahasa dengan bahasa Arab. Sebagai contoh adalah dengan mengajarkan perbedaan antara orang pertama, kedua dan ketiga dalam bahasa arab. Juga mengajarkan tentang perbedaan fi'il madhi dan mudhori'. Namun pengajaran terhadap persamaan harus lebih didahulukan dari pada mengajarkan perbedaanperbedaan diantara kedua bahasa.

7. Prinsip Tulisan Sebagai Pencatat Ujaran.

Pembelajaran bahasa Arab dengan mengajarkan bacaan dan tulisan sebagai usaha penyajian grafis unit- unit dan polapola bahasa yang telah diketahui peserta didik.

8. Prinsip Pola-Pola Bertahap.

Pembelajaran bahasa Arab dengan mengajarkan polapola secara berangsur, dalam langkah-langkah komulatif 
bertahap. Berkaitan dengan ini, maka dapat dilaksanakan dengan: memulai pembelajaran dengan kalimat- kalimat, memperkenalkan unsur-unsur bagian kalimat (seperti mubtadak, khobar, fa'il), menambahkan tiap unsur pola yang baru kepada yang terdahulu, menyesuaikan pelajaran yang sulit-sulit dengan kesanggupan para pelajar.

9. Prinsip Bahasa Versus Terjemahan.

Pembelajaran bahasa arab terlebih dahulu diajarkan sampai benar- benar dikuasai, baru terjemahan bisa diajarkan sebagai ketrampilan tersendiri.

10. Prinsip Bahasa Baku Otentik.

Pembelajaran bahasa Arab dengan mengajarkan bahasa Arab yang baku (standar) yaitu yang berasal dari dialek Quraisy yang dikembangkan dan disempurnakan dengan unsur- unsur dialek yang lain, yang sulit dibedakan dari kabilah tertentu bagi sang pengguna bahasa.

11. Prinsip Praktek.

Pembelajaran bahasa Arab adalah dengan memberikan waktu yang lebih banyak dalam praktek berbahasa Arab.

12. Prinsip Pembentukan Jawaban- Jawaban.

Pembelajaran bahasa Arab adalah dengan membentuk jawaban melalui sebagian pengalaman dan bimbingan.

13. Prinsip kecepatan dan Gaya.

Bimbingan bagi para pelajar bahasa Arab dalam berbahasa arab dapat dilakukan sama dalam kecepatan dan 
gayanya jika ia berbahasa dengan bahasa aslinya.

14. Prinsip Imbalan Segera.

Pembelajaran bahasa Arab yang dilakukan dengan sesegera mungkin membenarkan jawaban yang benar agar dapat memotivasi pelajar dalam melakukan yang sama.

15. Prinsip Sikap Terhadap Target Kebudayaan (Target Culture).

Pengenalan identitas kebudayaan penutur bahasa arab yang dipelajari oleh masyarakat tersebut, dan penumbuhan sikap empati terhadapnya. Sehingga akan menimbulkan sikap positif terhadap bahasa arab dari masyarakat tersebut.

16. Prinsip Isi.

Pengajaran isi ( segala sesuatu yang dipelajari atau meteri) seperti yang telah berkembang dalam kebudayaan tempat bahasa Arab diucapkan secara asli, atau dengan kata lain sesuai dengan perkembangan bahasa Arab di dunia Arab saat ini.

17. Prinsip Belajar Sebagai Hasil yang Kritis.

Pembelajaran bahasa Arab dengan tujuan untuk mendapatkan hasil belajar, bukan sekedar untuk menggembirakan atau menghibur. ${ }^{28}$

28 Abdul Mu'in, Analisis Kontrastif Bahasa Arab dan Bahasa Indonesia (Telaah terhadap Fonetik dan Morfologi), (Jakarta. Pustaka Al Husna Baru, 2004), hlm 138- 150. 


\section{Metodologi Pembelajaran Bahasa Arab}

Terdapat berbagai macam metode yang dapat digunakan dalam pengajaran bahasa diantaranya: direct method, natural method, psychological method, phonetic method, reading method, grammar method, translation method, grammar, eclectic method, unit method, language control method, mimicrymemoration method, practice- theory method, cognate method dan dual language method. ${ }^{29}$

Dari berbagai metode yang tertulis diatas, terdapat beberapa persamaan pengertian disamping perbedaannya. Oleh karena itu, berikut akan dijelaskan metode- metode yang sangat relevan untuk pengajaran bahasa Arab.

\section{Metode Gramatika-Terjemahan (Thoriqah al Qawa'id wa al} Tarjamah)

Metode Gramatika-Terjemahan adalah metode yang menekankan hafalan terhadap teks- teks asing dan terjemahannya. Adapun ciri-ciri metode ini adalah:

a. Tujuan mempelajari bahasa asing adalah agar mampu membaca buku atau naskah dalam baahasa arab.

b. Materi pelajaran terdiri atas buku tata bahasa, kamus dan teks bacaan yang berupa karya sastra klasik atau kitab keagamaan klasik.

c. Tata bahasa disajikan secara deduktif, yakni dimulai dengan penyajian kaidah diikuti dengan contoh- contoh.

29 Syamsuddin Asyrofi, Metodologi Pembelajaran Bahasa Ara, (Yogyakarta. Idea Press, 2010), hlm 96.

\section{IHTIMAM}


d. Kosa kata diajarkan dalam bentuk kamus dwibahasa atau daftar kosa katabeserta terjemahannya.

e. Proses pembelajarannya sangat menekankan penghafalan kaidah bahasa dan kosa kata, kemudian penerjemahan harfiyah dari bahasa sasaran ke bahasa siswa atau sebaliknya.

f. Bahasa ibu digunakan sebagai bahasa pengantar.

g. Peran guru sangat aktif sebagai penyaji materi, sementara siswa berperan pasif sebagai penerima materi.

\section{Metode Langsung (al-Thariqah al-Mubasyarah).}

Metode langsung adalah pembelajaran yang langsung menggunakan bahasa Arab dan secara intensif dalam berkomunikasi. Adapun ciri-ciri dari metode langsung adalah:

a. Materi pelajaran pertama-tama diberikan kata demi kata, setelah itu beralih kepada struktur kalimat. Pertama-tama diajarkan pengenalan huruf-huruf dengan tipikal tiap huruf yang berbeda (memperhatikan makhārij al-hurūf) seperti

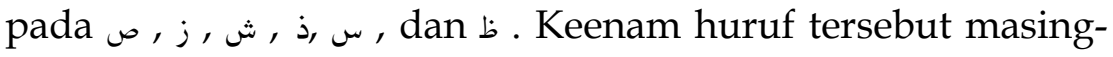
masing memiliki makhārij al-hurūf yang berbeda tetapi masing-masing dalam penyebutannya mengandung huruf "s" atau mendekatinya. Setelah hal ini dianggap rampung, barulah memasuki tahap-tahap pembentukan struktur kata ataupun menyusun huruf-huruf di atas dalam sebuah struktur kalimat yang sering dipakai ataupun dialami seperti dan sebagainya. 
b. Gramatika diajarkan hanya bersifat sambil lalu, siswa tidak dituntut menghafal rumus gramatika, tapi yang utama adalah mampu mengucapkan secara baik. Cara mengajarkan gramatika hanya sambil lalu sifatnya, maksudnya kaidahkaidah yang ada tidak harus dihafal, tetapi dibentuk situasi yang sedemikian rupa dan diperaktekkan secara lisan langsung.

c. Dalam proses pengajaran senantiasa menggunakan alat bantu ataupun alat peraga baik alat peraga langsung ataupun tidak langsung (benda tiruan). Juga biasanya menggunakan simbolsimbol ataupun gerakan-gerakan tertentu. Sebagai contoh, seorang guru mengisyaratkan pulpen yang ada ditangannya kemudian menyebutkan bahasa Arabnya, atau bisa juga dengan menunjukkan gambarnya.

d. Setelah memasuki kelas, siswa atau peserta didik benar-benar dikondisikan untuk menerima dan bercakap-cakap dalam bahasa Arab atau bahasa asing dan dilarang menggunakan bahasa lain. Misalkan seorang guru memasuki kelas dan mengucapkan salam ataupun menanyakan kabar mereka, menanyakan tanggal atau hari apa dan seterusnya, semuanya itu dengan menggunakan bahasa Arab.

e. Aktifitas belajar secara klasikal banyak dibimbing guru langsung praktek di dalam kelas, sedangkan di luar kelas peserta didik ditekankan untuk mempraktekkannya dengan kawan-kawan setingkat.

\section{IHTIMAM}


f. Porsi latihan mendengarkan lebih banyak untuk kemudian ditirukan. Ini bertujuan mempercepat peserta didik untuk mencapai pengetahuan bahasa secara otomatis.

g. Pada pengajaran bacaan, harus diberikan secara lisan terlebih dahulu, dengan jalan menunjukkan atau menuliskan katakata yang sukar satu per satu, kemudian menghubungkannya dalam bentuk kalimat dan alinea.

h. Sejak awal murid telah dilatih berfikir dalam bahasa Arab. Hal ini akan bermanfaat sekali dalam perkembangan selanjutnya. ${ }^{30}$

\section{Metode Membaca (Thariqah al-Qirâ'ah)}

Metode ini dikembangkan bersdasarkan asumsi bahwa pengajaran bahasa tidak bersifat multi-tujuan, dan bahwa kemampuan membaca adalah tujuan yang paling realistis ditinjau dan kebutuhan pembelajar bahasa asing. Adapun ciriciri metode membaca (Thariqah al-Qirấah) adalah sebagai berikut:

a. Tujuan utamanya adalah kemahiran membaca, yaitu agar pelajar mampu memaharni teks ilmiah untuk keperluan studi mereka.

b. Materi pelajaran berupa buku bacaan utama dengan suplemen daftar kosa kata dan pertanyaan-pertanyaan isi bacaan, buku bacaan penunjang untuk perluasan (qira'ah

\footnotetext{
${ }^{30}$ http:/ / bdkjakarta.kemenag.go.id/index.php?a=artikel\&id=844
} 
muwassa'ah), buku latihan mengarang terbimbing dan percakapan.

c. Basis kegiatan pembelajaran adalah memahami isi bacaan, didahului oleh pengenalan kosa kata pokok dan maknanya, kemudian mendiskusikan isi bacaan dengan bantuan guru. Pemahaman isi bacaan melalui proses analisis, bukan dengan terjemahan.

d. Membaca diam (qira'ah shâmitah) lebih diutamakan daripada membaca keras (qira'ah jahriyyah)

e. Kaidah bahasa diterangkan seperlunya, tidak boleh

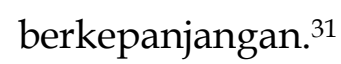

4. Metode Audio Lingual (al- Thariqah al Sam'iyah alSyafahiyah)

Pendekatan audiolingual didasarkan atas asumsi, antara lain bahwa bahasa itu pertama-tama adalah ujaran. Oleh karena itu pengajaran bahasa harus dimulai dengan memperdengarkan bunyi-bunyi bahasa dalam bentuk kata atau kalimat kemudian mengucapkannya, sebelum pelajaran membaca dan menulis. Asumsi lain ialah bahwa bahasa adalah kebiasaan. Suatu perilaku akan menjadi kebiasaan apabila diulang berkali-kali. Oleh Karena itu, pengajaran bahasa harus dilakukan dengan teknik pengulangan atau repetisi. Adapun ciri-ciri metode

${ }^{31}$ Ibid, Asyrofi, Syamsuddin, Metodologi, hlm. 102.

\section{IHTIMAM}


audiolingual (Ath-Thariqah asSam'yyah asy-Syafawiyyah) adalah sebagai berikut:

a. Tujuan pengajarannya adalah penguasaan 4 (empat) keterampilan berbahasa secara seimbang.

b. Urutan penyajiannya adalah menyimak dan berbicara, baru kemudian membaca dan menulis.

c. Model kalimat bahasa asing diberikan dalam bentuk percakapan untuk dihapalakan.

d. Penguasaan pola kahimat dilakukan dengan latihan-latihan pola (pattern-practice). Latihan atau drill mengikuti urutan: Stimulus response reinforcement.

e. Kosa kata dibatasi secara ketat dan selalu dihubungkan dengan konteks kalimat atau ungkapan, bukan sebagal katakata lepas yang berdiri sendiri.

f. Pengajaran sistem bunyi secara sistematis (berstruktur) agar dapat digunakan/ dipraktikkan oleh pelajar, dengan teknik demonstrasi, peniruan, komparasi, kontras, dan lain-lain.

g. Pelajaran menulis merupakan representasi dan pelajaran berbicara, dalam arti pelajaran menulis terdiri dan pola kalimat dan kosa kata yang sudah dipelajari secara lisan.

h. Penerjemahan dihindari. Pemakaian bahasa ibu apabila sangat diperlukan untuk penjelasan, diperbolehkan secara terbatas.

i. Gramatika (dalam arti ilmu) tidak diajarkan pada tahap permulaan. Apabila diperlukan pengajaran gramatika pada 
tahap tertentu hendaknya diajarkan secara induktif, dan secara bertahap dan yang mudah ke yang sukar.

j. Pemilihan materi ditekankan pada unit dan pola yang menunjukkan adanya perbedaan struktural antara bahasa asing yang diajarkan dan bahasa ibu pelajar. Demikian juga bentuk-bentuk kesalahan siswa yang sifatnya umum dan frekuensinya tinggi. Untuk ini diperlukan analisis kontrastif dan analisis kesalahan.

k. Kemungkinan-kemungkinan terjadinya kesalahan siswa dalam memberikan response harus sungguh-sungguh dihindarkan.

1. Penggunaan bahan rekaman, laboratorium bahasa, dan visual aids sangat penting.

\section{Metode Komunikatif (Al-Madkhal al-Ittashâliy).}

Secara umum, istilah metode komunikatif sering disamakan dengan pendekatan komunikatif. Oleh karena itu, pemaparan ciri- ciri metode komunikatif yang dipergunakan adalah dari pendekatan komunikatif. Adapun ciri- ciri pendekatan komunikatif (Al-Madkhal al-Ittashâliy) diantaranya:

a. Tujuan pembelajarannya ialah mengembangkan kompetensi pelajar berkomunikasi dengan bahasa target dalam konteks komunikatif yang sesungguhnya atau dalam situasi kehidupan yang nyata. Tujuan pendekatan komunikatif tidak ditekankan pada penguasaan gramatika atau kemampuan 
membuat kalimat gramatika, tetapi pada kemampuan memproduk ujaran yang sesuai dengan konteks.

b. Salah satu konsep yang yang mendasar dari pendekatan komunikatif adalah kebermaknaan dan setiap bentuk bahasa yang dipelajari dan keterkaitan bentuk, ragam, dan makna bahasa dengan situasi dan konteks berbahasa itu.

c. Dalam proses belajar-mengajar, siswa bertindak sebagai komunikator yang berperan aktif dalam aktivitas komunikatif yang sesungguhnya. Sedangkan pengajar memprakarsal dan merancang berbagai pola interaksi antar siswa, dan berperan sebagal fasilitator.

d. Aktivitas dalam kelas diwarnai secara nyata dan dominan oleh kegiatan komunikatif, bukan drill-drill manipulatif dan peniruanpeniruan tanpa makna (tadrib babghâ'iy)

e. Materi yang disajikan harus bervaniasi, tidak hanya mengandalkan buku teks, tapi lebih ditekankan pada bahanbahan otentik (berita koran, iklan, menu, KTP, SIM, dan sebagainya). Dan bahan-bahan otentik tersebut, pemerolehan bahasa pelajar diharapkan meliputi bentuk, makna, fungsi, dan konteks sosial.

f. Penggunaan bahasa ibu dalam kelas tidak dilarang sama sekali tapi diminimalkan.

g. Dalam PK, kesalahan atau kekeliruan siswa ditoleransi untuk mendorong keberanian siswa berkomunikasi. 
h. Evaluasi dalam PK ditekankan pada kemampuan menggunakan bahasa dalam kehidupan nyata, bukan pada penguasaan struktur bahasa atau gramatika.

\section{Metode Eklektik (Ath-Thariqah al-Intiqâ'iyyah).}

Konsep dasar metode ekletik (Ath-Thariqah alIntiqâ'iyyah) adalah bahwa metode ini didasarkan atas asumsi:

a. Tidak ada metode yang ideal karena masing-masing mempunyai segisegi kekuatan dan kelemahan.

b. Setiap metode mempunyai kekuatan yang biasa dimanfaatkan untuk mengefektifkan pengajaran.

c. Lahirnya metode baru harus dilihat tidak sebagal penolakan kepada metode lama, melainkan sebagai penyempurnaan.

d. Tidak ada satu metode yang cocok untuk semua tujuan, semua guru, semua siswa, dan semua program pengajaran.

e. Yang terpenting dalam pengajaran adalah memenuhi kebutuhan pelajar, bukan memenuhi kebutuhan suatu metode.

f. Setiap guru memiliki kewenangan dan kebebasan untuk memilih metode yang sesuai dengan kebutuhan pelajar. ${ }^{32}$

32 http:/ /ichazahramustafavi.blogspot.co.id/2010/12/metode-metodepengajaran-bahasa-arab.html. Selasa, 11 Oktober 2016.

\section{IHTIMAM}




\section{Kesimpulan}

Pada setiap pembelajaran tentu sangat penting dalam penentuan metodologi di dalamnya, agar tujuan dari pembelajaran tersebut dapat tercapai dengan baik dan secara efektif. Begitu pula dalam pembelajaran bahasa Arab. Terdapat macam-macam metode dalam pembelajaran bahasa Arab yaitu:

1. Metode Gramatika-Terjemahan (Thorigah al Qawa'id wa al Tarjamah)

2. Metode Langsung (al-Thariqah al-Mubasyarah).

3. Metode Membaca (Thariqah al-Qirấah)

4. Metode Audio Lingual (al- Thariqah al Sam'iyah al-Syafahiyah)

5. Metode Komunikatif (Al-Madkhal al-Ittashâliy).

6. Metode Eklektik (Ath-Thariqah al-Intiqấiyyah). 


\section{Daftar Pustaka}

Abdul Mu'in, Analisis Kontrastif Bahasa Arab dan Bahasa Indonesia (Telaah terhadap Fonetik dan Morfologi), Jakarta. Pustaka Al Husna Baru, 2004

Dengeng, I. N. S, Kerangka Perkuliahan dan Bahan Pengajaran. Jakarta, Proyek Pengembangan Lembaga Pendidikan Tenaga Kependidikan, 1989

Depdiknas, Kamus Besar Bahasa Indonesia. Jakarta. Balai Pustaka, 2008

Ulin Nuha, Metodologi Super Efektif Pembelajaran Bahasa Arab, Diva Press : Jogjayakarta, 2000

http:/ / bdkjakarta.kemenag.go.id/index.php?a=artikel\&id=844. Selasa, 11 Oktober 2016

http:/ /ichazahramustafavi.blogspot.co.id/2010/12/metodemetode-pengajaran bahasa-arab.html. Selasa, 11 Oktober 2016.

Syamsuddin Asyrofi, Metodologi Pembelajaran Bahasa Arab, Yogyakarta, Idea Press, 2010 